\title{
INNOVATIVE WASTEWATER TREATMENT AS A PREREQUISITE FOR THE USE OF SLUDGE IN AGRICULTURE
}

\author{
Blaženka Piuković Babičkovićc , ŽeljkoVojinović ${ }^{2}$ Predrag Vukadinović ${ }^{3}$
}

\begin{abstract}
Summary
This paper is based on the research done in water supply companies on the territory of Vojvodina in the Republic of Serbia. The paper presents an innovative model for wastewater treatment, because wastewater treatment and the disposal of sludge, produced during such treatment, are issues to be tackled not only by the Republic of Serbia, but also other countries in the region and elsewhere. The aim of the paper is to point out, how correct wastewater and sludge treatment can produce sludge, which has valuable agronomic properties. The paper seeks to encourage the correct use of sludge in agriculture in line with Directive 86/278/EEC, adopted by the Council of the European Economic Community to promote the use of sludge in agriculture on reasonable grounds, by ensuring its proper use.
\end{abstract}

Keywords: waste water treatment, sludge, agriculture.

JEL: $Q 19, Q 53$

\section{Introduction}

It is a generally known fact, that we have less and less drinking water supplies at our disposal due to high consumption and even higher levels of pollution. The fact that the above statement covers a global problem calling for serious attention, is also supported by the data of the UN, according to which, there 1.5 billion people now, who don't have access to clean, drinking water, and in the next 25 years that number will increase to around 5.4 billion.

1 Blaženka Piuković Babičković, Ph.D., Tax Administration Subotica, Ministry of Finance, Korzo no. 5, Subotica, Serbia, Phone:+381 24655 129, E-mail: piukovic.b@gmail.com.

2 Željko Vojinović, Ph.D., Assistant Professor, University Novi Sad, Economic faculty Subotica, Segedinski put Street no. 9-11, Subotica, Serbia, Phone: +381 24628 030, E-mail: zeljko.vojinovic@ef.uns.ac.rs.

3 Predrag Vukadinović, Ph.D., Assistant Professor, University Singidunum, Faculty of Business Belgrade, Danilova Street no. 32, Belgrade, Republic of Serbia, Phone: +381 63216 908, E-mail: pvukadinovic@singidunim.ac.rs

EP 2016 (63) 2 (471-484) 
The production and distribution of water, as well as the drainage and treatment of wastewater, are of crucial significance for life and survival on our planet, therefore it deserves special attention by the society as a whole.

The Republic of Serbia is in a group of European countries that have a series of problems with water supply and wastewater treatment. Thus, there is an obvious need for intensified and more significant investment of resources in the process of developing water supply companies, whereby, beyond equipment and tools, investments should also be made in knowledge, new technologies and innovation in company organization and management, market development, etc.(Ahmetagić, Piuković, Lukić, 2011).The transformation of water supply companies and the improvement of their business operations are vital preconditions of the overall economic development and Serbia's EU accession alike (Bogdanović, 2005; Lukić, 2008).

The aim of this paper is to provide the water supply companies with a justification for introducing process organisation and for its viability, by pointing out the correlation between the implementation of the business process management concept and the quality of achieved performances. Furthermore, the paper seeks to emphasize the importance of process decomposition and to show on a concrete example how to decompose a process into logically relating process parts. It facilitates the understanding of the process flow and the functioning of the process, and, also, the management of the business process. The paper also seeks to call the attention to the potentials of using ecosystem technologies and solving the problem of sewage sludge as a residual product of wastewater treatment plants. Pursuant to the Council Directive on the protection of environment, and in particular of the soil, when sewage sludge is used in agriculture (86/278/EEC), correctly treated sewage sludge can successfully be used in agriculture as well. The aim of the mentioned Directive is to regulate the use of sewage sludge in such a way as to prevent harmful effects on soil, vegetation, animals and man, while encouraging the correct use of sewage sludge (Council Directive, Article 1).

Only achieving significant progress in the implementation of business process management concept can help water supply companies to fulfil and maintain all requirements set by international standards in this area (such as ISO 9000, ISO 14000, HACCP). Compliance with the stipulations of the indicated Directive 86/278/EEC by the Council of the European Economic Community, relating to EU Member States, is one of the necessary steps the Republic of Serbia has to take on its way of EU accession.

\section{Accepting Process Approach, as a Precondition for Successful Monitoring and Achieving the Organization's Objectives}

"In the past, organizations have focused their efforts on making effective decisions within a facility. In this case, the various functions of an organization, including assembly, storage, and distribution are generally decoupled into their functional and geographic components through buffers of large inventories. In this way, the complexity of the decisions is reduced since each component is treated independently of the others. 
Ignoring these component dependencies, however, can have costly consequences. This becomes increasingly apparent with market globalization. As a result, firms are moving from decoupled decision making processes toward more coordinated and integrated design and control of all of their components in order to provide goods and services to the customer at low cost and high service levels" (Thomas, Griffin, 1996).

The world renowned theorist, Peter Drucker (2002), points out that it is organization, that has to become the key subject of change, because the most effective way to successfully manage changes is that the changes initiate themselves.

Process approach emphasizes the fact that every organization is a set of inter-connected processes, and implementing a process-based organizational structure should be the result of efforts invested by all the individual participants in processes. Thereby, customer awareness is fully included in this approach and it holds a primary place inside it (Anupindi, Chopra, Deshmukh, Mieghem, Zemel, 2012).

Business Process Management (BPM) is one of the vital issues for many organisations, because, if successfully adopted, it can bring about significant advantages to the organization, such as: better understanding of business processes, a higher level of control and significantly better business performance (Buh, Kovačič, Štemberger, 2015).

"Organisation is fully carried out through business processes. The process is a set of interconnected activities with interactions, which are transforming the object (input) into a result (output), in a way that employees (people) are adding to it a certain procedural value, using the resources of the organization" (Radosevic, Baosic, Caric, Jovanovic, Beric, Bojic, Avramovic, 2014).

Business process management as a comprehensive managerial approach of introducing the process-based concept in organization includes the design and modelling of the business processes, implementing the process and measuring its effectiveness.

Porter (1985) called the attention to the demand for process management, as well as the need to measure the realization of the set objectives, both at the level of the entire process and the level of the sub-processes and specific tasks alike.

Appointing a process owner and forming a management team are assumptions for the start of management and development of every key process. The process owner has the task and responsibility to keep the system functioning as a whole (Bosilj, Hernaus, Kovačić, 2008).

A company's business flow should start from objectives, strategic orientation, and the design of organisation, and, in order to successfully implement its strategy, methods are necessary as well, which should be selected and implemented, likewise an adequate documentation basis, IT support, defining competencies, measuring and specifying performances, and the required communication which closes the circle of a company's business flow.

Presenting business activities in the order of their appearance immensely facilitates 
the understanding of the business flow processes, thus, it significantly eases the way of spotting certain critical activities, so it opens up a space for suggestions and proposals, and alternative ideas for improving the processes.

The modelling of processes serves as a documentation, and also represents a kind of user manual, which describes complex business processes. Business process analysts decide about the level of details to be considered during modelling. The creativity, knowledge and expertise of the business process analysts, as well as of the entire modelling team come to expression. The result achieved by modelling largely depends on the available time, the organization of the system that is analysed, on the communication with the users of the system, as well as on other similar factors.

Modelling has a great significance in the process of creating or setting up an organization's BPM, because setting up process organisation, actually, starts by modelling standard processes. The first things to be identified are business processes, then comes the modelling of process types, and parallel with that, the organisation is redesigned, i.e. accommodated to the business process management concept. The next stage is BP planning which is a key factor in the process of BPM. In this stage the first approach is to identify the process needs, and then the modelling of instances using standard values is performed. Simultaneously, the plan of capacity and the time schedule are being drawn up, and the design of the process flows starts. In the third stage, called BP management and planning, the modelling of process instances using actual values and alternatives is carried out, and instances are optimized by their respective sequences and the model is transformed into a feasible model. Simultaneously, the aggregation and redesigning of the model by instances is performed, and in the final stage come observation and control, which synergistically leads to automatic implementation (Scheer, Feld, Casper, 2012).

Based on the above stated, it can be concluded that the successful implementation of a business process managing concept requires serious, planned and organized approach.

\section{Identifying and Defining the Key Business Process}

Process orientation is the main means of process evaluation and learning the ways to create, restructure and lead processes aimed at improving performance. (Anupindi et al., 2012).

Identifying and defining business processes are important questions for every organization, which wants to conduct structural changes from the traditional internal focus on the hierarchy to a structure that is flexibly oriented towards consumers. The initiative for changing business processes should be started by the top management. (Žabjek, Kovačič, Indihar, Štemberger, 2008).

By defining primary (basic) business processes in water supply companies, weactually illustrate the way these companies should meet the needs of their consumers. Exactly for this reason, when we define them, it is absolutely necessary to clearly understand 
the core activities of the company and the values it creates for its consumers, and, besides that, it is also essential to understand how the units of the organization approach the major tasks, which are to be solved jointly. Namely, we consider the existence and functions of an organisation, its business ideas, vision and strategy, but, itis alsoessential to understand theresults of the organization's strategic analysis and its business situation.

Companies, dealing with potable water production and supply, and wastewater drainage and treatment, should be, first and foremost, guided by the regulations and Directives relating to environment protection while making decisions about their business mission, vision and strategy. A vision, based on environment protection emphasizes the meaning of work and has the strength to gather all employees around a common vision of the future. Environment protection should be a strategic question, which will be in the focal point in defining business processes in companies for wastewater treatment.

Depending on business factors, as well as the perception, approach, experience, knowledge and creativity of managers, it is fundamental to identify the key business processes in companies, which are, in the opinion of top managers, of critical importance to business, so they shall be managed in the forthcoming period. Thus, it is required to start with the improvement of the key and the most problematic processes (Janićijević, 2010).

\section{Presentation and Analysis of the Wastewater Treatment Process}

During the research in companies for water supply, in a particular company, "wastewater drainage and treatment" has been identified as a key business process. The significance of wastewater drainage from households and from industrial companies, as well as the atmospheric waters that are collected through drains, their treatment and purification in accordance with the specified standards, along with theobviousneed for capacity increase and improvement of processes, affected the selection of this key business process.

Special attention was paid to the process of wastewater treatment during the implementation of the research in water supply companies, because of the below indicated reasons. The National Waste Management Strategy, valid for the period of 2010-2019 (Official Journal of the Republic of Serbia no. 29/10), adopted by the Government of the Republic of Serbia, calls the attention to a highly alarming situation in the field of wastewater treatment. Namely, according to the data published in the mentioned Strategy, only 46 percent of the households are connected to the sewage system in the Republic of Serbia, while the quantity of communal wastewater is 363,1 million cubic meters/year. Only 5,3percent of the total wastewater quantity is treated appropriately, while the residual sludge is disposed in landfills. As the quantity of wastewater to be treated and of the residual sludge has been increasing day by day, the National Waste Management Strategy brings forward, that sludge should be treated in line with the EU regulations. The Strategy foresees, that the stabilized residual sludge from wastewater treatment will be used in agriculture, for thermal treatment in incinerators and as a fuel in cement works, while the rest will be disposed. 
In the next chapters, the paper will provide the presentation of an innovative wastewater treatment process, which is compliant with international standards.

\section{Innovative Wastewater Treatment Process}

The innovative process of wastewater treatment includes a water line and a sludge line.

The water line is a modern and innovative flow of activities in wastewater treatment, because each sub-process has been significantly improved and it includes:

1. Wastewater drainage.

2. Mechanical treatment of wastewater.

3. Biological treatment of wastewater.

The sludge line is a flow of activities performed during primary and secondary sludge treatment, i.e. the sludge is separated during wastewater treatment and this process includes:

1. Energy production

Table 1.Drainage and wastewater treatment (TO-BE model)

\begin{tabular}{|l|l|l|}
\hline \multirow{2}{*}{$\begin{array}{l}\text { Process } \\
\text { limits: }\end{array}$} & Starting activity: & \multicolumn{1}{|l|}{$\begin{array}{l}\text { Drainage of atmospheric and communal wastewater to } \\
\text { wastewater plant }\end{array}$} \\
\cline { 2 - 3 } & Final activity: & Discharge of treated water according to 91/271 EEC \\
\hline Process entry & Exit from process \\
\hline - City communal wastewater & $\begin{array}{l}\text { - Treated water according to 91/271 EEC } \\
\text { - SCADA system }\end{array}$ & $\begin{array}{l}\text { - Stabilized sludge } \\
\text { - Elogas }\end{array}$ \\
\hline Sub-processes & Description in documents \\
\hline $\begin{array}{l}\text { 1. WATER LINE- purification of water } \\
\text { 2. SLUDGE LINE- Energy production }\end{array}$ & $\begin{array}{l}\text { 1. sub-process list 2.1, 2.1.1, 2.1.2, 2.1.3 } \\
\text { 2. sub-process list 2.2 }\end{array}$ \\
\hline User & \begin{tabular}{l} 
Demands/expectations of users \\
\hline
\end{tabular} \\
- Community & $\begin{array}{l}\text { - Treated water according to 91/271 EEC } \\
\text { the costs of plant. } \\
\text { - Enterprise }\end{array}$ \\
\hline Resources & $\begin{array}{l}\text {-Using stabilized sludge in accordance with its } \\
\text { properties. }\end{array}$ \\
\hline
\end{tabular}




$\begin{aligned} & \text {-Personnel in accordance with the job systematization plan } \\ & \text {-Infrastructure (Entering pumping station, primary sedimentation tank, biological tank, } \\ & \text { secondary sedimentation tank, building for press, hoods, silo for sludge, gas reservoir, building } \\ & \text { gas generator, command building, laboratory) }\end{aligned}$
-Machinery (pumps, mixers etc.)
-Automatic (switches, fuses, PLC, SCADA)
-Laboratory equipment (flow meter, sensors, gauges pressure, temperature gauge, gauges PH
value)

Source: Piukovic, 2013

The innovative business process of wastewater treatment now includes the sub-process of wastewater treatment, called "water line" and the sub-process of producing energy, called "sludge line". The complete innovative process is monitored by the logs of the SCADA(supervisory control and data acquisition-SCADA) system. Ostroff (1999) stressed the importance of information technology and its use in process-oriented organizations, because it makes process monitoring and implementation easier, simpler and faster. Owing to the use and support of IT systems, companies and specialized departments can focus on their core competencies and processes, and it also provides a faster flow of information which leads to improved processes and the development of competitive advantage (Kuhn, 2011). Therefore, monitoring wastewater treatment by the SCADA system records represents a massive improvement and a step forward compared to the previous method of monitoring and documenting business processes. 
Draining wastewater to the treatment plant is a way of transporting wastewater via collector systems to the wastewater treatment plant. At the point, where wastewater enters the inlet works through a pumping station, wastewater samples are taken by an automatic sampler to measure the values of chemical oxygen demand (COD), biological oxygen demand (BOD), dry matter (DM), total nitrogen (TN) and total phosphorous (TP). The inlet flowrate is also measured. After the wastewater entered the inlet works and the accomplished lab analysis, the following parameters are recorded, which are measured in the plant: COD amounting $511 \mathrm{mg} / \mathrm{l}$, BOD amounting $183 \mathrm{mg} / \mathrm{l}$, dry matter amounting $321 \mathrm{mg} / \mathrm{l}$, total nitrogen amounting to $45 \mathrm{mg} / \mathrm{l}$ and total phosphorous amounting to $7 \mathrm{mg} / \mathrm{l}$. All measurements are logged in the SCADA system.

The mechanical treatment of wastewater in the innovative process includes the filtration of wastewater through coarse and fine screens, wastewater treatment in a sand trap and in primary sedimentation tank. Waste is collected besides the coarse screen and taken away in containers after the relevant measurement. The number of containers transported is duly recorded. Waste is also collected beside the fine screen and its quantity is recorded as well. That waste is disposed in a point for waste disposal. Wastewater is further treated in a sandtrap and the amount of sand that is collected is measured and taken to waste disposal point. In order to determine if at least $85 \%$ of particles larger than 0,2micrometres have been removed, particles separated after sand trap treatment are measured and a report on the concentration of dry matter is made. Wastewater treatment in the sand trap is crucial and the above indicated target performances have to be achieved, because if the amount of the removed sand is not appropriate, then the remained sand could accelerate the breakdown of the pumps. After the sand trap, the wastewater flows to the primary sedimentation tank, where primary sludge sedimentation takes place. Here, the flow rate of the primary sludge is measured and recorded. After the mechanical treatment, wastewater is treated biologically, and the primary sludge is used in the electricity production sub-process.

The biological treatment of wastewater in the innovative process is significantly improved and it includes the following activities: transporting the wastewater to the biological treatment plant, wastewater treatment in the anaerobic and the anoxic zones, wastewater treatment in the nitrification and disinfection tank, additional aeration in the old biological treatment tank, transporting to additional sedimentation tanks and discharging treated water. During the biological treatment of the wastewater, the concentration of oxygen is measured and its target value should range from of 0,5 to $2 \mathrm{mg} / \mathrm{l}$. During the discharge of treated water, target values to be achieved are: ammonium - below $1 \mathrm{mg} / \mathrm{l}$, nitrate - below 0,3 mg/1, COD should be $125 \mathrm{mg} / \mathrm{l}$, BOD should be $25 \mathrm{mg} / 1$, DM $30 \mathrm{mg} / 1$, total nitrogen $10 \mathrm{mg} / 1$ and total phosphorous $1 \mathrm{mg} / 1$. The output of this sub-process is treated wastewater in accordance with the 91/271 EEC standards and secondary sludge that will be used together with the primary sludge in the electricity production sub-process. Measurements made during the above listed activities are innovations, because they are implemented in the most contemporary way, continuously, and documented by the records of the SCADA system. In order to 
provide better monitoring and control, performances, units of measurements, starting values, target values, the frequency of measurement and measurement/control points should be specified in thesub-process lists.

The energy production sub-process, called the "sludge line" includes the following activities: primary sludge thickening in gravity thickener, secondary sludge thickening ingravity thickener band, discharging primary and secondary sludge to digestion tanks, where the anaerobic digestion of the sludge is made in order to produce biogas, delivering of biogas into compressors to increase pressure, processing of biogas in a gas engine, collection of stabilized sludge in a tank and its pressing in band press. The quality of the treated water, biologically active sludge and its density are measured. Then, the thickened primary and secondary sludge are treated in a digestion tank, where anaerobic digestion is performed in order to produce biogas. At this point, it is essential to measure the quality and temperature of biogas. The temperature should be between $30-37{ }^{\circ} \mathrm{C}$, the $\mathrm{pH}$ value should be between $6,8-7,5 \mathrm{pH}$, biogas consumption should be around $2700 \mathrm{~m}^{3}$, the amount of hydrogen sulphide should be below $200 \mathrm{ppm}$, and the quality of gas should be $55 \%$. Biogas is then delivered to compressors, where its pressure is increased. By processing biogas in gas engines, electricity is produced, and its target value is $240 \mathrm{kWh}$.

The output of this sub-process is stabilized sludge with $20 \%$ of dry matter content, and electrical and thermal energy. Thanks to the production of its own electrical energy, the company can satisfy around $50 \%$ of its power consumption needs, and it is a significant saving. This sub-process is also accompanied by permanent measurements and control of sub-process performances thus ensuring the managing of the business process.

\section{The Use of Sewage Sludge in Agriculture}

Sewage sludge comprises of a huge amount of water, dry matters containing organic matters, nutrients, heavy metals and organic pollutants and pathogenic microorganisms. Depositing sludge next to the wastewater treatment plant, the above indicated sludge pollutants, which are in a concentrated form, get back to the environment, and it is a potential hazard for human health and the environment. For this very reason, the interest in sludge production, depositing and recycling is growing in Europe (Karlović, 2010).

The 86/278/EEC Directive (further as: Directive) regulates and encourages the use of sewage sludge in agriculture in a way that prevents any harmful impact on the soil, vegetation, animals and man. EU Member States, by virtue of their common market, in compliance with the Directive and its annexes I A, I B and I C, are bound to observe the stipulations, which specify the conditions and limit values which should be fulfilled during sludge treatment and its use for agricultural purposes.

In compliance with Article 4 of the Directive, annexes I A, I B and I C specify the values for the concentration of heavy metal in the soil, on which the sludge is used, the concentration of heavy metals in the sludge and the maximum annual quantities of these heavy metals which may be introduced in the soil intended for agriculture. 
In accordance with Annex II A, before sludge is used in agriculture, it should be analysed and such an analysis should cover the following parameters: dry matter, organic matters, $\mathrm{pH}$, nitrogen, phosphorous, cadmium, copper, nickel, lead, zink, mercury, chromium.

Annex I B sets the limit values for heavy metal concentrations in sludge for use in agriculture ( $\mathrm{mg} / \mathrm{kg}$ of dry matter) and it is shown in the table below.

Table 2. Limit values for heavy metal concentrations in sludge for use in agriculture

\begin{tabular}{|l|c|}
\hline \multicolumn{1}{|c|}{ Parameters } & $\begin{array}{c}\text { Limit values } \\
\text { (mg/kg of dry matter) }\end{array}$ \\
\hline Cadmium & 20 to 40 \\
Copper & 1000 to 1750 \\
Nickel & 300 to 400 \\
Lead & 750 to 1200 \\
Zink & 2500 to 4000 \\
Mercury & 16 to 25 \\
Chrome & - \\
\hline
\end{tabular}

Source: Directive 86/278/EEC

Member States regulate the use of sludge in agriculture under the condition, that the accumulation of heavy metals in the soil shall not exceed the set limit values. They determine the maximum sludge quantity expressed in tonnes of dry matters, which may annually be used on soil per area unit, and shall observe the limit values for the heavy metal concentrations in sludge, which are indicated in Table 2.

For the case of using sludge in agriculture, the Directive has been supplemented by a Working Document on Sludge - third draft EC 2000, which suggests, that, besides checking heavy metal, organic compounds should also be considered:

1.AOX-sum of halogenated organic compounds,

2.LAS- Linear alkylbenzenesulphonates,

3.DEHP-Di(2-ethylhexyl)phthalate,

4.NPE-Nonylphenol and nonylphenolethoxylates with 1 or 2 ethoxy groups,

5.PAH- polycyclic aromatic hydrocarbons,

6.PCB- polychlorinated byphenils,

7. Polychlorinated dibenzodioxins and dibenzofuranes.

In line with the Directive, it is prohibited to use or supply sludge for the use on:

-"grassland or forage crops if the grassland is to be grazed or the forage crops to be harvested before a certain period has elapsed" and that period shall not be shorter than three weeks;

- "soil in which fruit and vegetable crops are growing, with the exception of fruit trees; 
-ground intended for the cultivation of fruit and vegetable crops which are normally in direct contact with the soil and normally eaten raw for a period of 10 months preceding the harvest of the crops and during the harvest itself."

With responsible treatment before use and accomplishing the prescribed detailed analyses of sludge and soil, sludge may be used in a way that the nutrient needs of plants are taken in consideration and that soil, surface and underground water quality is not deteriorated.

EU Member States are bound to observe the above referred Directive and all its Annexes, which specify the necessary sludge and soil analyses, the referent methods of sampling and analysing, storing updated data about the accomplished analyses and submitting all required data to the competent authorities.

The use of sludge in agriculture is based on the nutrient content of the sludge. Namely, by the decomposition of organic sludge components to anorganic they infiltrate in clay and humus particles and facilitate the growth of plants. The organic components in the sludge improve the structure of the soil and enable its aeration and improves its ability to keep moisture. Besides nitrogen, phosphorous and potassium, sludge also contains iron, manganese, zinc, copper, boron and molybdenum and it all contributes to the better growth of plants (Šišić, Bikić, Avdić, 2015).

\section{Conclusion}

Water supply companies should transform their organisation from traditional to business process-oriented one, and product and service quality management should be a permanent process for them.

In order to achieve successful progress in business process management, it is essential, that the company's basic approach to process-oriented management, customer satisfaction and permanent improvements must not be just empty phrases, but an integral part of the company's organisational culture (Rentzhog, 2000).

The paper has specifically presented a breakdown (decomposition) of a key business process, i.e. wastewater drainage and treatment, to logically pertaining process parts. The presented decomposition may be of great assistance to companies operating in the field of wastewater treatment. Special attention is paid to the presentation of sludge management in the wastewater treatment plant.

On its ways to full-fledged EU membership, the Republic of Serbia should pay special attention to environment protection. The aim of the paper was to prompt the correct management of residual sludge from wastewater treatment in line with the EU regulation. Innovating the wastewater treatment process and applying acceptable technologies will have a positive impact on environment protection. Eco-remediation, as a biotechnology implies the use of biological, environmentally acceptable technologies by using different microorganisms and green plants to eliminate various pollutions. The selection of the solution to be applied in treating communal sludge should be based on 
its environmental acceptability.

The use of sludge in agriculture has a number of advantages (Šišić et al., 2015):

- decreased use of fertilizers,

- less production costs,

- improved fertility and structure of the soil,

- maintaining optimum moisture, improving the permeability of soil,

- enriching the soil with organic ingredients,

- recirculation of phosphorous compounds, already exhausted on global level,

- decreased possibility for erosion.

In EU Member States, after the correct and responsible treatment of the sewage sludge, about 45 percent of the treated sludge is used in agricultural production. Treated sludge may have valuable agronomic properties, therefore its use is encouraged. In the Republic of Serbia a lot has to be done on raising awareness about the use of sludge in agriculture and on responsible conduct of those companies, which deal with wastewater treatment.

\section{References:}

1. Ahmetagić, E.,Piuković, B., Lukić, D. (2011): Business Process Management and Organization Innovativeness, Strategic management - International Journal of Strategic Management and Decision Support Systems in Strategic Management Vol.16, No 4, pp 37-44.

2. Anupindi, R., Chopra, S., Deshmukh, D.S., Van Mieghem, J.A., Zemel, E. (2012): Managing Business Process Flows. Pearson, New Jersey.

3. Bogdanović, S. (2005): EU Framework Directive on Water. Novi Sad Yugoslav Association for Water Law.

4. Buh, B., Kovačič, A., Štemberger, M. (2015): Critical success factors for different stages of business process management adoption - a case study. Economic Research - Ekonomska Istraživanja, Vol. 28, No. 1, pp. 243-258, available at: http://dx.doi.or g/10.1080/1331677X.2015.1041776.

5. Bosilj, V.V., Hernaus, T., Kovačić, A. (2008): Upravljanje poslovnim procesimaorganizacijski i informacijski pristup. Školska knjiga, Zagreb.

6. Drucker, P. (2002): Upravljanje u novom društvu. Adižes, Novi Sad.

7. Janićijević, N. (2010): Procesni pristup u organizacionoj analizi i promenama. Ekonomika preduzeća, no.11/12 2010.

8. Karlović, E. (2010): Muljevi od prečišćavanja komunalnih otpadnih voda legislativa, korišćenje i tretman muljeva. available at: http://www.cecra.dh.pmf.uns. ac.rs/pdfww2010/ELVIRA\%202010\%20MULJEVI\%20OD.pdf. 
9. Kuhn,T. (2011): Wettbewerbsfahig dank Business Analyse. Journal Zeitschrift Führung und Organisation.

10.Lukić, D. (2008): Vodosnabdevanje-razvojne mogućnosti i primena benčmarkinga. Memorija, Sombor.

11. Ostroff, F. (1999): The Horizontal Organization, Oxford University Press, New York.

12.Piukovic, B. (2013): Upravljanje poslovnim procesima u javnim komunalnim preduzećima za vodosnabdevanje, doktorska disertacija, Ekonomski fakultet $\mathrm{u}$ Subotici, Univerzitet u Novom Sadu, Republika Srbija.

13.Porter, M.E. (1985): Competitive Advantage: Creating and Sustaining Superior Performance. New York: The Free Press.

14.Radosevic, M., Baosic, M., Caric, M., Jovanovic, V., Beric, D., Bojic, Z., Avramovic N. (2014): Implementation of Business Process Reengineering in Human Resource Management. Inzinerine Ekonomika - Engineering Economics, 2014, Vol. 25, No. 2, pp. 211-222.

15.Rentzhog, O. (2000): Temelji preduzeća sutrašnjice. Prometej, Novi Sad.

16.Scheer, A.W., Feld,T., Casper, R. (2012): IM Die Fachzeitschrift für Information Management und Consulting, Available at: http://www.scheer-management.com/ wp-content/uploads/2012/07/IM-2012-Ausgabe2-Senderdruck_DE_Homepage.pdf

17.Šišić,M.., Bikić, F., Avdić, N. (2015): Ekološki prihvatljivi načini zbrinjavanja muljeva zaostalih na komunalnim uređajima za prečišćavanje otpadnih voda. Available at: http:/www.quality.unze.ba/zbornici/QUALITY\%202015/075-Q15061.pdf

18. Thomas, D.J., Griffin, P.M. (1996): Coordinated supply chain management. European Journal of Operational Research, Vol. 94, No.1, pp. 1-15.

19.Žabjek, D., Kovačič, A., Indihar Štemberger, M. (2008): Business process management as an important factor for a successful ERP system implementation. Economic Research - Ekonomska Istraživanja, Vol.21, no.4. pp.1-18. Avaiable at: http:/hrcak.srce.hr/index.php?show=clanak\&id_clanak_jezik=60008.

20.Direktiva Saveta o zaštiti životne sredine, a posebno zemljišta, pri korišćenju kanalizacionog mulja u poljoprivredi 86/278/EEC, Savet Evropske zajednice.

21.Strategija upravljanja otpadom za period 2010 - 2019. godine (S1.glasnik RS br. 29/10). 


\title{
INOVIRANO PREČIŠĆAVANJE OTPADNIH VODA KAO PREDUSLOV ZA KORIŠĆENJE MULJA U POLJOPRIVREDI
}

\author{
Blaženka Piuković Babičkovič ${ }^{4}$, ŽeljkoVojinovič́ ${ }^{5}$, Predrag Vukadinovićc ${ }^{6}$
}

\begin{abstract}
Sažetak
Ovaj radsezasniva na istraživanju kojeje sprovedeno u preduzećima za vodosnabdevanje koja se nalaze na području Vojvodine u $R$. Srbiji. U radu je predstavljen inovirani model prečišćavanja otpadnih voda iz razloga što se sa problemom prečišćavanja otpadnih voda i odlaganjem mulja koji nastaje nakon prečišćavanja susreće $R$. Srbija kao i mnoge zemlje u regionu ali i šire. Cilj ovoga rada je da ukaže kako se pravilnim prečišćavanjem otpadnih voda kao i pravilnim tretmanom mulja koji nastaje nakon prečišćavanja, može doći do mulja koji ima vredna poljoprivredna svojstva. Ovaj rad želi da podstiče ispravnu primenu mulja u poljoprivredi u skladu sa Direktivom 86/278/ EEC, koja je doneta od strane Saveta Evropske zajednice a kojom se želi opravdano podsticati primena mulja u poljoprivredi uz obezbeđenje da se ispravno koristi.
\end{abstract}

Ključne reči: prečišćavanje otpadnih voda, mulj, poljoprivreda.

4 Dr Blaženka Piuković Babičković, Ministarstvo finansija, Poreska uprava Subotica, Korzo br. 5, 24000 Subotica, Srbija, Telefon:+38124655129, E-mail: piukovic.b@gmail.com

5 Docent, dr Željko Vojinović, Ekonomski fakultet Subotica, Univerzitet u Novom Sadu, Segedinski put br. 9-11, 24000 Subotica, Srbija, Telefon: +38124628030, E-mail: zeljko. vojinovic@ef.uns.ac.rs.

6 Docent, dr Predrag Vukadinović, Univerzitet Singidunum, Fakultet Poslovna Ekonomija Beograd, Danilova ulica br. 32, Beograd, Republika Srbija, Telefon: +381 63216908 , E-mail: pvukadinovic@singidunim.ac.rs 